\title{
Factors associated with cognitive performance of non-demented elderly outpatients
}

\section{Fatores associados ao desempenho cognitivo de idosos não demenciados}

\author{
Denise Ribeiro Stort Bueno', Daniele Clini Belintani' ${ }^{2}$ Flavia Silva Arbex Borim ${ }^{3}$, Maria Elena Guariento ${ }^{4}$ \\ ' School of Medical Sciences, State University of Campinas (FCM/Unicamp), Campinas, SP. < destort@hotmail.com> \\ 2 School of Medical Sciences, State University of Campinas (FCM/Unicamp), Campinas, SP. < dany.belintani@hotmail.com> \\ ${ }^{3}$ Department of Clinical Sciences, State University of Campinas, Campinas, SP. < flarbex@hotmail.com> \\ ${ }^{4}$ School of Medical Sciences, State University of Campinas (FCM/Unicamp), Campinas, SP. <meguar@fcm.unicamp.br>
}

\section{ARTICLE INFO}

\section{Article history}

Received: 22/02/2016

Accepted: 17/06/2016

\section{Correspondent Author}

Denise Ribeiro Stort Bueno

Rua Orestes Manara, 344

Pq. da Imprensa

13806-352 Mogi Mirim, SP, Brasil

<destort@hotmail.com>

\section{(C) 2016 All rights reserved}

\section{Editors}

Alfredo Cataldo Neto

Paula Engroff

\begin{abstract}
Objective: To evaluate the cognitive performance of non-demented elderly and its relation to sociodemographic, clinical and biochemical variables. Methods: 71 subjects $(\geq 60$ years) were studied. Sociodemographic data were collected in interviews; MMEM was used to assess cognition, the clinical variables were taken from the patient's medical record, and biochemical measurements were taken through blood tests which measured serum levels of vitamin $B_{12}$, TSH and CRP. Results: Most of the subjects were women, older than 80 years old, with education between 1 and 4 years. Most of them had no diagnosis of diabetes mellitus, dyslipidemia, thyroid dysfunction or osteoporosis, and had their blood levels within the normal range; hypertension was present in $81 \%$ of patients. The average MMSE showed significant relation to gender, education and dyslipidemia; the presence of this diagnosis was related to better cognitive performance. Conclusion: This study suggests that elderly monitored by specialized health service can receive treatment for managing symptoms of morbidity and comorbidities, controlling, among others, cardiovascular risk factors, thus protecting them from suffering cognitive loss.
\end{abstract}

KEYWORDS: Elderly; Geriatrics service; Cognition; Clinical and biological variables.

\section{RESUMO}

Objetivo: Avaliar o desempenho cognitivo de idosos em atendimento ambulatorial, não demenciados e a relação deste com variáveis sociodemográficas, clínicas e bioquímicas. Metodologia: Foram estudados 71 sujeitos ( $\geq 60$ anos). Dados sociodemográficos foram coletados através de entrevista; para avaliar a cognição utilizou-se o MEEM, as variáveis clínicas foram coletadas do prontuário médico do paciente e as medidas bioquímicas através de exame de sangue que dosou níveis séricos de vitamina $B_{12}$, TSH e PCR. Resultados: A maior parte dos sujeitos eram mulheres, com mais de 80 anos e escolaridade entre 1 e 4 anos. A maioria não tinha diagnóstico de diabete melito, dislipidemia, disfunção tireoidiana, osteoporose e estavam com seus níveis séricos dentro da normalidade; hipertensão arterial esteve presente em $81 \%$ dos pacientes. A média do MEEM mostrou relação significativa com gênero, escolaridade e dislipidemia, a presença deste diagnóstico foi relacionada com melhor desempenho cognitivo. Conclusão: Este estudo sugere que idosos acompanhados em serviço de saúde especializado podem receber tratamento e assim monitorar os sintomas das morbidades e comorbidades, controlando, entre outros, os fatores de risco cardiovascular, protegendo-os assim de sofrerem perda cognitiva.

PALAVRAS-ChaVe: Idosos; Serviço de geriatria; Cognição; Variáveis clínicas e biológicas. 


\section{INTRODUCTION}

Cognitive aging is a complex phenomenon that holds great intra and inter-individual variability. Knowing this process is of great importance, since the maintenance of cognition is a determinant of the quality of life in old age and cognitive decline is associated with discomfort, disability, loss of independence and increased social costs ${ }^{1}$.

Cognitive assessment is an important part of care for the elderly. The Mini Mental State Examination (MMSE), developed by Folstein et al. ${ }^{2}$, is one of the most widely used screening instruments worldwide. In Brazil, it has been widely evaluated for the score values, and adjustments to the cut-off points according to the level of education of individuals were proposed ${ }^{3}$. In addition to its use in clinical practice, it has been used in studies with different methodologies, and the majority of the studies using this instrument shows a relationship between cognitive performance and age, gender, education, health and lifestyle ${ }^{4}$.

The increase in the aging population results in higher prevalence of chronic conditions related to cognitive decline and the development of dementia ${ }^{5}$. Cardiovascular, endocrine-metabolic and musculoskeletal diseases may be related to worse cognitive performance $e^{6,7,8}$, although there are literature data contradicting this statement ${ }^{9}$. Serum levels of vitamin $\mathrm{B}_{12}$, thyroid-stimulating hormone (TSH) and $\mathrm{C}$-reactive protein (CRP) may also be associated with change in cognitive functioning in aging ${ }^{10,11,12,13}$.

It is important to note that the best understanding of the impact of the variables related to cognitive performance of elderly, particularly in developing countries, and efforts for diagnosis and early detection of consequences of normal and pathological decline in this population represent an important public health issue ${ }^{14}$.

Thus, this study aimed to evaluate the cognitive performance of elderly with no clinical evidence of dementia treated at the Geriatric Outpatient Service of Unicamp Clinical Hospital, and the relationship of this parameter with sociodemographic variables (age, gender and education level), clinical variables (diagnosis of hypertension, diabetes mellitus, dyslipidemia and osteoporosis) and biochemical variables (levels of vitamin $\mathrm{B}_{12}$, TSH and CRP).

\section{MATERIAL AND METHODS}

\section{Sample}

It is a cross-sectional study. The sample consisted of 71 subjects aged 60 years or older, monitored in the Geriatric Outpatient Service of a tertiary public hospital. For this study, the inclusion criteria adopted were people aged 60 years; no clinical suspicion or diagnosis of dementia or physical, sensory and mental limitations to perform cognitive assessment. Exclusion criteria were elderly with hypothetical or confirmed diagnosis of dementia; elderly unable or unavailable to be submitted to cognitive test and blood collection.

\section{Procedures}

The local Research Ethics Committee approved without restrictions the Protocol of this research (Resolution 466/2012 CNS/MS) and the Free and Clarified Consent Term. The procedures followed the standards of this Committee. The subjects received detailed information about the research procedures and the research began after they signed the Free and Clarified Consent Term.

The cognitive assessment was performed using the Mini Mental State Examination (Folstein et al., 1975), consisting of seven categories that assess specific cognitive functions, such as orientation, immediate memory and episodic memory, attention, calculation, language and visual-constructional ability. The scores from this instrument were treated as a continuous variable in a range from 0 to 30 .

In order to obtain the sociodemographic data, a semi-structured interview with subjects containing socio-demographic information was conducted. A search through medical records was conducted to obtain clinical and diagnosis data considered in this study (according to International Classification of Diseases - 10). These variables were categorically treated (presence or absence of diagnosis and altered or normal blood test, respectively).

Data were collected by the researcher during clinical activities. Seniors who attended the consultation and met the criteria were invited to participate in the survey, which took place in a single meeting, before or after medical consultation. After applying the proposed instruments, the subjects received a blood test request for analysis of levels of vitamin $B_{12}, T S H$ and CRP, and were referred to the Hospital Clinical Pathology Laboratory, where their blood was collected. Analyses were performed by the laboratory and the results were attached to medical records and verified by the researchers.

The choice of the clinical variables considered in this study was based on observation of the four most common diseases in the service (systemic arterial hypertension, thyroid dysfunction, osteoporosis and diabetes mellitus, respectively). Biochemical variables as levels of TSH, vitamin $B_{12}$ and $C R P$ that may be associated with impaired cognitive function were considered. In addition, the measurement of these parameters does not require previous fasting, which facilitated the logistics of blood collection for this purpose. 


\section{Data analysis}

For the analysis of this research, prevalence estimates and 95\% confidence intervals were produced. After performing the Shapiro-Wilk test, a normal distribution in MMSE scores was found. Therefore, for analysis of numerical variables T-Student parametric tests (for comparison between two groups) and ANOVA tests (for comparison among three or more groups) were performed. The analyses of univariate and multivariate regression to estimate the variables that presented more significant association with worse cognitive performance were also used. The significance level adopted for all statistical tests was 5\% $(p<0.05)$.

\section{RESULTS}

By means of descriptive analysis, it was verified that the majority of subjects were female $(70.4 \%)$, aged 80 years and older $(47.9 \%)$ and had education between 1 and 4 years $(50.7 \%)$. In relation to clinical variables, there was a predominance of individuals who did not have diabetes mellitus (81.7\%), thyroid dysfunction (67.6\%), dyslipidemia (56.3\%) and osteoporosis (67.6\%); systemic arterial hypertension was the diagnosis present in most of the individuals assessed (81.7\%). The results of the blood tests showed normal levels of TSH, vitamin $\mathrm{B}_{12}$ and CRP in most subjects $(76.0 \%, 85.3 \%$ and $66.1 \%$, respectively).

An average of $22.9 \pm 3.5$ points on the MMSE was observed. As shown in Table 1, the cognitive performance of the subjects in this test showed a significant difference by gender $(p<0.003)$ and education $(p<0.001)$. Men had higher average, and when divided into educational ranges, the illiterate elderly performed worse, but the significance appeared only in the group with over 5 years of education compared to those who had never studied. Different age groups showed no differences in MMSE average $(p>0.460)$.

Table 1. Average and standard deviation of the MMSE compared to sociodemographic variables

\begin{tabular}{lcc}
\hline & $\begin{array}{c}\text { MMSE } \\
\text { Average (SD) }\end{array}$ & $p$-value \\
\hline Gender (\%) & & \\
$\quad$ Male $(29.6 \%)$ & $24.80(3.12)$ & 0.003 \\
$\quad$ Female $(70.4 \%)$ & $22.12(3.46)$ & \\
Age $(\%)$ & & \\
$\quad 60-69(21.1 \%)$ & $21.86(4.35)$ & \\
$70-79(30.0 \%)$ & $23.09(3.16)$ & 0.460 \\
80 y.o. or older $(47.9 \%)$ & $23.21(3.44)$ & \\
Education $(\%)$ & & \\
$\quad$ Never studied $(22.6 \%)$ & $20.75(2.84)$ & \\
$1-4$ years $(50.7 \%)$ & $22.77(3.66)$ & 0.001 \\
5 years or more $(26.7 \%)$ & $24.89(2.86)$ & \\
\hline
\end{tabular}

MMSE: Mini Mental State Examination; SD: Standard deviation.
Table 2 shows that the relationship between cognitive performance and diagnostics of diabetes mellitus, systemic arterial hypertension, thyroid dysfunction and osteoporosis was not statistically significant. Only the presence of dyslipidemia positively influenced the subjects' performance on the MMSE. Although it is not significant, there was a trend of better cognitive performance among elderly who had the diagnoses above. Levels of TSH, vitamin $\mathrm{B}_{12}$ and CRP also showed no statistically significant relation with the average score on the MMSE.

Table 2. Average and standard deviation of the MMSE compared to clinical and biological variables

\begin{tabular}{|c|c|c|}
\hline & $\begin{array}{c}\text { MMSE } \\
\text { Average (SD) }\end{array}$ & $p$-value \\
\hline $\begin{array}{l}\text { Diabetes mellitus (\%) } \\
\text { No }(81.7 \%) \\
\text { Yes }(18.3 \%)\end{array}$ & $\begin{array}{l}22.82(3.59) \\
23.15(3.53)\end{array}$ & 0.776 \\
\hline $\begin{array}{l}\text { Arterial hypertension }(\%) \\
\text { No }(18.3 \%) \\
\text { Yes }(81.7 \%)\end{array}$ & $\begin{array}{l}22.23(4.06) \\
23.05(3.45)\end{array}$ & 0.466 \\
\hline $\begin{array}{l}\text { Thyroid disorder }(\%) \\
\text { No }(67.6 \%) \\
\text { Yes }(32.4 \%)\end{array}$ & $\begin{array}{l}22.64(3.91) \\
23.40(2.64)\end{array}$ & 0.409 \\
\hline $\begin{array}{c}\text { Dyslipidemia }(\%) \\
\text { No }(56.3 \%) \\
\text { Yes }(43.7 \%)\end{array}$ & $\begin{array}{l}22.10(3.62) \\
23.93(3.24)\end{array}$ & 0.032 \\
\hline $\begin{array}{l}\text { Osteoporosis }(\%) \\
\text { No }(47 \%) \\
\text { Yes }(23 \%)\end{array}$ & $\begin{array}{l}22.72(3.83) \\
23.21(2.96)\end{array}$ & 0.589 \\
\hline $\begin{array}{l}\text { TSH }(\%) \\
\text { No change }(76.0 \%) \\
\text { Decreased levels }(2.80 \%) \\
\text { Increased levels }(21.20 \%)\end{array}$ & $\begin{array}{l}23.00(3.51) \\
24.50(0.70) \\
22.26(3.95)\end{array}$ & 0.638 \\
\hline $\begin{array}{l}\text { Vitamin } \mathrm{B}_{12}(\%) \\
\text { No change }(85.30 \%) \\
\text { Decreased levels }(7.35 \%) \\
\text { Increased levels }(7.35 \%)\end{array}$ & $\begin{array}{l}24.43(10.56) \\
23.00(4.06) \\
20.40(3.91)\end{array}$ & 0.669 \\
\hline $\begin{array}{l}\text { CRP }(\%) \\
\text { No change }(66.10 \%) \\
\text { Changed }(33.9 \%)\end{array}$ & $\begin{array}{l}23.0(3.12) \\
22.5(4.43)\end{array}$ & 0.617 \\
\hline
\end{tabular}

TSH: Thyroid stimulating hormone; CRP: C-reactive protein.

Table 3. Multiple linear regression model (stepwiseforward) of the global MMSE score as a dependent variable, considering gender, education and diagnosis of dyslipidemia as independent variables.

\begin{tabular}{lcccc}
\hline & $\mathbf{R}^{2}$ & $\mathbf{B}$ & $\mathbf{I C ~ 9 5 \%}$ & $\boldsymbol{p}$-value \\
$\begin{array}{lcccc}\text { Model 1 } \\
\quad \text { Education }\end{array}$ & 0.17 & 2.07 & $0.97-3.17$ & 0.0000 \\
$\quad \begin{array}{l}\text { Model 2 } \\
\quad \text { Education }\end{array}$ & & & & \\
$\quad$ Gender & 0.23 & -2.04 & $-3.75--0.32$ & 0.020 \\
$\quad$ Model 3 & & & & \\
$\quad$ Education & & 1.59 & $0.52-2.66$ & 0.004 \\
$\quad$ Gender & & -2.30 & $-3.97--0.63$ & 0.008 \\
$\quad$ Dyslipidemia & 0.30 & 1.79 & $0.29-3.28$ & 0.019 \\
\hline
\end{tabular}


Variables with $p<0.10$ were added in the multiple regression model. They were introduced one by one, from the smallest to the largest value of $\mathrm{p}$, generating 3 models. The performance of the subjects on the MMSE was 30\%, explained by the presence of gender differences, education and diagnosis of dyslipidemia (Table 3).

\section{DISCUSSION}

In the present study it was observed that the majority of the investigated group was women, which can be attributed to factors such as a higher prevalence of women among that age; they seek medical assistance more frequently compared to men, and finally women have higher survival rates, however with more chronic diseases, described as feminization of old age ${ }^{15}$. Regarding age, there was a significant proportion of elderly aged 80 and over; this finding may be associated with a referral bias in a reference service, and also complies with other studies that investigated the population treated at geriatric outpatient services, and that is also due an increase of this age group in the population ${ }^{16}$.

The service where this research was conducted prioritizes the care of elderly people over 80 years, or the presence of the main geriatric syndromes, a fact that contributes to this age profile. Low education is a characteristic that has been registered in users of other geriatric outpatient services ${ }^{17}$; Brazilian Institute of Geography and Statistics (IBGE) ${ }^{8}$ data show that among the population aged 60 and over, the average education was 3.8 years, and these characteristics match the sample. Low education affects both the elderly considered more robust, as well as those treated in outpatient medical specialties ${ }^{17}$.

The aging process makes the individual more likely than to developing chronic diseases. These diseases are defined as conditions accompanying individuals for a long period of time; in Brazil, 75\% of elderly reported having at least one chronic disease ${ }^{19}$. Research shows high prevalence of systemic arterial hypertension in people over 60; figures of up to $65 \%$ of hypertensive individuals among the elderly heve been registered, and among women over 75 years this prevalence can reach $80 \%{ }^{20}$. These data are consistent with the findings of this survey, where $81.7 \%$ of subjects had this chronic illness. The occurrence of diabetes mellitus and dyslipidemia diagnoses are similar to what is found in literature. Regarding the diagnoses of thyroid dysfunction and osteoporosis there are variable results in the research, and, in this sample, these results were above the figures recorded in the literature; elderly accompanied by specialized health service go through clinical evaluation and perform additional tests, factors that favor the diagnosis of certain diseases and may explain the results of this research, where the elderly outpatients have a higher prevalence of thyroid dysfunction and osteoporosis compared to elderly community $21,22,23,24$.

The vast majority of elderly participants of this study had normal levels of TSH, vitamin $\mathrm{B}_{12}$ and $\mathrm{CRP}$, which possibly associates with the outpatient follow-up, where the biochemical profile is often screened and changes are tracked.

The impact of socio-demographic variables on cognitive aging is a consensus in the gerontological literature. Lower MMSE scores among elderly people with low education is observed in studies with different samples ${ }^{25,26}$. The results of this research are consistent with the literature, and it is well established that illiteracy and limited formal education represent risks and can lead to cognitive decline in old age ${ }^{27}$.

Data on the correlation between gender and cognitive performance reported in the literature are conflicting; in this study, belonging to male gender positively influenced the cognitive performance of the subjects, a fact confirmed by Fei et al. ${ }^{28}$. The difference between gender and cognition, among other factors, may be modulated by education, and also by incentives and opportunities experienced in different manners throughout life for older women and men.

Unlike the results found in other studies ${ }^{4}$, the influence of the variable age on the cognitive performance of the subjects was not observed in this sample. The fact that the average MMSE is not significantly lower among older people can be explained by the criteria related to the inclusion of the elderly in outpatient services mentioned above, where this research was conducted.

It has been demonstrated that risk factors for cardiovascular diseases may influence the incidence of cognitive decline in old age and in the development of dementia ${ }^{29}$. But the role of hypertension, diabetes mellitus and dyslipidemia in determining loss in cognitive function in the elderly is not a consensus. Some studies have found an association between these variables and the worsening of cognitive function; other investigations have found the contrary or have not proven this relationship ${ }^{30,31,32}$.

Results of this research showed a significant association between the presence of dyslipidemia and better cognitive performance; which can be explained by three main guidelines: the first one is related to the non-drug treatment for this condition, which refers to the prescription of physical activity, low-fat diet and combat smoking, factors considered cognitive decline protectors in aging ${ }^{33,34}$. The second one would be related to the fact that the diagnosis of dyslipidemia lead to treatment and controlling the levels of high density 
lipoproteins (HDL) and low density lipoproteins (LDL); there is evidence that the decrease in total cholesterol, especially low LDL and increasing HDL, reduce the incidence of heart attack and other cardiovascular diseases that may cause cognitive decline and dementia framework ${ }^{35}$. The last one, still controversial and without clear evidence, would be related to the protective effect of statins (drugs most commonly used to treat dyslipidaemia); according to some studies, this drug has effects that cause a better blood irrigation of the tissues with increased synthesis of nitric oxide, a substance that cause a dilation of arteries and act as a potentially protective drug cognitive deterioration ${ }^{36,37}$.

There was no relationship between systemic arterial hypertension and diabetes mellitus on cognition, but there was a better performance trend on the MMSE among subjects who had these two diagnoses. These findings may be due to better control and treatment of these morbidities and health professional guidance that induces the subject to adopt healthier lifestyles, which might improve and protect the cognitive decline of the elderly ${ }^{38}$. These facts may also explain the lack of relationship between cognitive performance and the presence of other diagnoses considered (thyroid dysfunction and osteoporosis).

No associations were observed between changes in serum levels of TSH, vitamin $B_{12}$ and CRP with cognitive performance in this study. Regarding TSH levels, a prospective cohort study showed that low levels of this hormone can predict a future risk of cognitive decline in the elderly. The same study demonstrated an association between low levels of TSH and the risk of Mild Cognitive Impairment (MCI) and dementia ${ }^{12}$. However, another study found no significant association between thyroid function (measured by levels of THS and T4) and the main areas of cognitive ability, which is similar to the results observed in this research. Bégin et al. ${ }^{39}$ concluded, after extensive review, that there is little or no consensus in the literature about how thyroid function is associated with cognitive performance of older people.

Vitamin $B_{12}$ can also be used to identify and attempt to reverse cognitive and functional deficits in elderly individuals. It is known that a deficiency of this vitamin can be associated with a progressive atrophy of the brain and consequent cognitive decline ${ }^{10}$. Another study showed that in patients with MCI, low levels of this vitamin have not been associated with cognitive deficits, but its deficiency could precipitate the onset of symptoms ${ }^{40}$. Moore et al..$^{41}$ concluded, after review of 43 studies on the subject, that vitamin $B_{12}$ deficiency may precede cognitive decline, but there is insufficient evidence to determine if this condition causes cognitive decline and neurodegenerative diseases. In this sample, the longitudinal observation of these variables would better explain this relationship. Besides the transversal bias limiting this analysis, the number of elderly who presented alterations in $B_{12}$ levels is very small and can interfere with the results of this association.

The serum levels of CRP, which is a non-specific inflammatory marker, have been associated with cognitive impairment ${ }^{11}$. There is also evidence that increasing the serum levels of CRP can be a biochemical marker that makes it possible to identify individuals with an increased risk of cognitive deficit ${ }^{42}$. A study in coronary patients showed that CRP levels were inversely associated with cognitive performance, regardless of age, gender and education, and those with CRP levels $\geq 5 \mathrm{mg} / \mathrm{L}$ were 2.9 times more likely to have cognitive deficits compared to controls ${ }^{43}$. In the present study the level of CRP was not considered as a numeric variable, which may have influenced the absence of an association with worse cognitive performance.

Important limitations of this study deserve consideration: besides the small sample, it was consideret only healthy patients from the cognitive point of view (these patients are accompanied by a multidisciplinary team that performs clinical, cognitive and laboratory tests systematically ensuring the absence of diagnosis of dementias framework among the selected elderly to this research), which can be associated to the results with no significance. Because these are elderly outpatients, most of the subjects had biochemical parameters within the normal range, which can be related to the performance in the MMSE. Moreover, the systemic blood pressure was not measured at the time of cognitive testing because the aim of the study was to work with clinical diagnosis. Time and treatment of each disease were also not considered, conditions that can contribute to the variability of the cognitive performance of the elderly. Cholesterol levels and fractions and blood sugar were also not measured because patients would need to fast, a condition which was not possible by the time the collection was taken.

This study suggests the importance of diagnosing the diseases that commonly affect the elderly, and from diagnosis, to treat, guide and monitor them so that they are better protected from cognitive decline. The results of this research point to the need for continued research, considering the normal and pathological cognitive aging and its relationships with health variables and the different types of interventions for the treatment of these variables. 


\section{REFERENCES}

1. Yassuda MS. Memória e o envelhecimento saudável. In Freitas EV, Py L, Neri AL, Cançado FAX, Gorzoni ML, Rocha SM (Eds). Tratado de geriatria e gerontologia. Rio de Janeiro: Guanabara Koogan, 2002.

2. Folstein M, Folstein S, McHugh P. Mini-Mental State. A pratical method for grading the cognitive status of patients for the clinical. Journal of Psychiatr Research. 1975;12: 189-198.

3. Bertolucci PHF, Brucki SMD, Campacci S, Juliano Y. O Mini-Exame do Estado Mental em uma população geral. Impacto da escolaridade. Arq Neuropsiquiatr. 1994; 52:1-7.

4. Valle EA, Castro-Costa E, Firmo JOA, Uchoa E, Lima-Costa MF. Estudo de base populacional dos fatores associados ao Mini Exame do Estado Mental entre idosos: Projeto Bambuí. Cad Saúde Pública, Rio de Janeiro. 2009;25(4):918-926.

5. Yassuda MS, Viel TA, Silva TBL, Albuquerque MS. Memória e Envelhecimento: Aspectos Cognitivos e Biológicos. In: Freitas EV, Py L, Cançado FAX, Doll J, Gorzoni ML. Tratado de Geriatria e Gerontologia. 3르 ed. Rio de Janeiro: Guanabara Koogan, 2011.

6. Fisher AL, Frias CM, Yeung SE, Dixon R. Short-term longitudinal trendas in cognitive performance in olderadultswithtype 2 diabetes. Journal of Clinical and Experimental Neuropsychology. 2009;31(7):808-822.

7. Sweat V, Starr V, Bruehi H, Arentolf A, Tirsi A, Javier E, Convit A. C- Reative Protein is Linked to Lower Cognitive Performance in Overweigth and Obese Women. 2008; 31(3):198-207.

8. Ho AJ, Raji CA, Becker JT, Lopez OL, Kuller LH, Hua X et al. Cardiovascular Health Study; ADNI. Obesity is linked with lower brain volume in $700 \mathrm{AD}$ and MCI patients. Neurobiol Aging. 2010;31(8):1326-1339.

9. Leite MT, Hildebrandt LM, Kirchner RM, Winck MT, Silva LAA, Franco GP. Estado cognitivo e condições de saúde de idosos que participam de grupos de convivência. Rev Gaúcha Enferm. 2012;33(4):64-71.

10. Gröber U, Kisters K, Schmidt J. Neuroehancement with Vitamin B12 - Underestimated Neurological Significance. Nutrients. 2013;5(12):5031-5045.

11. Kuo KH, Yen CJ, Chang CH, Kuo CK, Chen JH, Sorond F. Relation of C-rective protein to stroke, cognitive disorders, and depression in the general population: systematic review and meta-analysis. The Lancet Neurology. 2005;4(6): 371-380.

12. Moon JH, Park YJ, Kim TH, Han JW, Sung HC, Lim S, Park DJ, Kim KW, Jang HC. Lower-but-normal serum TSH level is associated with development or progression of cognitive impairment in elderly: Korean Longitudinal Study on Health and Aging (KLosSHA). J Clin Endocrinol Metab. 2014;99(2):424-432.

13. Booth T, Deary IJ, Starr JM. Thyroid stimulating hormone, free thyroxine and cognitive ability in old age: The Lothian birth cohort study 1936. Psychoneuroendocrinology. 2013;38(4):597-601.

14. Neri AL, Neri ML. Envelhecimento cognitivo. In: Freitas EV, Py L, Neri AL, Cançado FAX, Gorzoni ML, Rocha SM (eds.). Tratado de Geriatria e Gerontologia. Rio de Janeiro: Guanabara Koogan; 2011. p. 1461-76.

15. Louvison MC, Lebrão ML, Duarte YA, Santos JL, Malik AM, Almeida ES. Inequalities in access to health care services and utilization for the elderly in São Paulo, Brazil. Rev Saúde Pública. 2008;42(4):733-40.
16. Leal MC, Marques AP, Marino JG, Rocha EC, Santos CR, Austregésilo SC. Profile of aged outpatients and duration of stay at a gerontologic-geriatric clinic. Rev Bras Geriatr Gerontol. 2009;12(1):77-86.

17. Linhares CR, Guimarães RM, Campos AP, Carvalho NT, Coelho VL. Patients' profile at a geriatric outpatient service in Federal District, Brazil. Psicol reflex crít. 2003;16(2):319-26.

18. IBGE. Síntese de indicadores sociais, 2006. Disponível em: http://www.ibge.org.br

19. Alves LC, Leite IC e Machado CJ. Perfis de saúde dos idosos no Brasil: Análise da Pesquisa Nacional por Amostra e Domicílio de 2003 utilizando o método Grade of Membership. Cad saúde Pública. 2008;24(3):535-46.

20. Souza A, Costa A e Nakamura D. Um estudo sobre hipertensão arterial sistêmica na cidade de Campo Grande, MS. 2007;88(4):441-6.

21. Freitas EV. Diabetes Melito. In: Freitas EV, Py L, Cançado FAX, Doll J, Gorzoni ML. Tratado de Geriatria e Gerontologia. Rio de Janeiro: Guanabara Koogan; 2011. p. 1461-75.

22. Moriguchi EM, Vieira JLC. Dislipidemia em Idosos. In Freitas EV, Py L, Cançado FAX, Doll J, Gorzoni ML. Tratado de Geriatria e Gerontologia. Rio de Janeiro: Guanabara Koogan; 2011. p. 1461-75.

23. Nasri F. Alterações de Tireoide e Paratireoide no Idoso. In Freitas EV, Py L, Cançado FAX, Doll J, Gorzoni ML. Tratado de Geriatria e Gerontologia. Rio de Janeiro: Guanabara Koogan; 2011. p. 1461-75.

24. Neto JFM. Osteoporose. In Guariento ME, Neri AL. Assistência Ambulatorial ao Idoso. Campinas: Alínea; 2010. p. 109-14.

25. Alvarenga MR, Oliveira MA, Faccenda O. The social and functional profile of elderly persons assisted by the family health strategy. Cogitare Enferm. 2011;16(3):478-85.

26. Batistoni SS, Bueno DR, Di Nucci FC, Yassuba MS. Status cognitivo, satisfação com a cognição e sintomas depressivos. In: Neri AL, Guariento ME (orgs.). Fragilidade, saúde e bem-estar em idosos: dados do estudo FIBRA Campinas. Campinas: Alinea; 2011.

27. Bottino MC, Azevedo DJR, Tatscha M, Hotatian SR, et al. Estimate of dementia prevalence in a community sample from São Paulo. Dementia Geriatric Cong Disord. 2008; 26(4):291-9.

28. Fei M, Qu YC, Wang T, Yin J, Bai JX, Ding H. Prevalence and distribuition of cognitive impairment no dementia (CIND) among the age population and tha analysis of sócio-demographic characteristics: The community-based cross-sectional study. Alzheimer Dis Assoc Disord. 2009; 23(2):130-8.

29. Solfrizzi V, Panza F, Colacicco AM, Dİntrono A, Capurso C, Torres F, et al. Vascular risk factors, incidence of MCI, and rates of progression of dementia. Neurology. 2004;63: 1882-91.

30. Plassman BL, Willians Jr JW, Burke JR, Holsinger T, Benjamin S. Systematic Review: Factors Associated With Risk for and Possible Prevention of Cognitive Decline in Later Life. Ann Intern Med. 2010;153(3):182-93.

31. Di Nucci FRCF, Coimbra AMV, Neri AL, Yassuda MS. Ausência de relação entre hipertensão arterial sistêmica e desempenho cognitive em idosos de uma comunidade. Rev Psiq Clin. 2010;37(2):52-6.

32. Freitag MH, Peila R, Masaki K, Petrovich H, Ross GW, White LR, et al. Midlife pulse pressure and incidence of dementia. The Honolulu-AsiaAging Study. Stroke. 2006;37:33-7. 
33. Fatores associados ao melhor desempenho cognitive global em idosos do município de São Paulo, Estudo SABE (dissertação de mestrado). São Paulo, 2011.

34. Eizeri KDP, Manfroi WC. Educação de pacientes com dyslipidemia: Revisão sistemática. Rev Bras Fram. 2008; 89(3):207-10.

35. Natarajar S, Glick H, Criqui M, Horowitz D, Lipsitz SR, Kinosian B. Cholesterol measure to identify and treat individual at risk for coronary heart disease. American Journal of Preventive Medicine. 2003;25(11):601-4.

36. Jick H, Zornberg GL, Jick SS, Seshadi S, Drachaman DA. Statins and the risk of dementia. Lancet. 2000; 356(9242):1627-31.

37. RocKwood K, Darvesh S. The risk of dementia in relation to statins and other lipid lowering agents. Neurological Research. 2003;25(6):601-4.

38. Middleton LE, Yaffe K. Promissing strategies for the prevention of dementia. Arch Neurol. 2009;66:1210-5.
39. Bégin ME, Langlois MF, Lorrain D, Cunnane SC. Review atticle: Thyroid function and cognition durin aging. Current Gerontology and Geriatrics Research. 2008.

40. Silva D, Albers U, Santana I, Vicente M, Martins IP, Verdelho A, Guereiro M, Mendonça A. Do MCI patients with vitamin B12 deficiency have distinctive cognitive déficits? BMC Res Notes. 2013;6:357.

41. Moore E, Mander A, Ames D, Carne R, Sanders K, Watters D. Cognitive Impairment and vitamin B12: a review. International Psychogeriatrics. 2012; 24(4):541-546.

42. Komulainen P, Lakka TA, Kivipelto M, et al. Serum high sensitivity $\mathrm{C}$-reactive protein and cognitive function in elderly women. Age ageing. 2007;36(4):443-448.

43. Rizzi L, Marques FC, Rosset I, Moriguchi EH, Picon PD, Chaves MLF, Roriz-Cruz M. C-Reactive Protein and Cognition Are Unrelated to Leukoaraiosis. Sci World J. 2014;8 p. 